\title{
A comparison of the suitability of different willow varieties to treat on-site wastewater effluent in an Irish climate
}

\author{
S.J. Curneen*, L.W. Gill
}

Enviranmental Engineering Group, Department of Civil Structural and Enviranmental Engineering University of Dublin, Trinity College, Dublin 2, Ireland

\section{Abstract}

Short rotation coppiced willow trees can be used to treat on-site wastewater effluent with the advantage that, if planted in a sealed basin and sized correctly, they produce no effluent discharge. This paper has investigated the evapotranspiration rate of four different willow varieties while also monitoring the effects of three different effluent types on each variety. The willow varieties used are all cultivars of Salix viminalis. The effluents applied were primary (septic tank) effluent, secondary treated effluent and rain water (control). The results obtained showed that the addition of effluent had a positive effect on the evapotranspiration. The willows were also found to uptake a high proportion of the nitrogen and phosphorus from the primary and secondary treated effluents added during the first year. The effect of the different effluents on the evapotranspiration rate has been used to design ten full scale onsite treatment systems which are now being monitored.

\section{Keywords}

- On-site wastewater;

- Willow beds;

- Zero discharge;

- Evapotranspiration;

- Crop coefficient

\section{Introduction}

Over $40 \%$ of Ireland's population live outside of urban areas making the country one of the most ruralised in Europe (CSO, 2012). As a result, most of these dwellings are not connected to a public sewer system, and hence require some form of on-site wastewater treatment before disposal to surface water or (more commonly) to groundwater. On-site treatment usually consists of a septic tank, which provides limited anaerobic treatment (Canter and Knox, 1985; Beal et al., 2005) or a secondary aerobic treatment unit, which then discharge effluent to the subsoil via a percolation area. However, in some regions the subsoil is of very low permeability (normally due to heavy clay soils) which would not be able to percolate the typical on-site hydraulic loads and so an al ternative form of treatment and disposal is required. In addition, a new Code of Practice for on-site wastewater treatment in Ireland (EPA, 2009) has introduced a minimum field saturated hydraulic conductivity $\left(k_{\mathrm{fs}}=0.47 \mathrm{~m} \mathrm{~d}^{-1}\right)-$ as determined on site by a falling head percolation test (Mulqueen and Rodgers, 2001) - below which the discharge of on-site effluent to ground is not permitted. County Wexford, which is located in the south east of Ireland, is one such region which has considerable deposits of clay ("marl") subsoils. In the last decade, during the construction boom, the Local

\footnotetext{
* Corresponding author. Tel.: +353 18961047; fax: +353 16773072 . E-mail address: curneensetcd.ie (S.J. Curneen)
}

Authority granted hundreds of planning permissions for single houses, for which on-site treatment consisted of a septic tank followed by a discharge of the effluent to a nearby stream. However, subsequently many of the streams and rivers throughout the county have been suffering from poor water quality - the Environmental Quality Standard (EQS) for phosphorus in rivers in Ireland is set at $0.035 \mathrm{mg} \mathrm{L}^{-1}$ - with on-site effluent considered to be the major contributor to this problem. To address this, the Local Authority has implemented a series of full-scale trials using zero discharge willow bed systems to treat the effluent.

Due to its relatively high transpiration rate (Hall et al., 1998; Pauliukonis and Shneider, 2001) willow is seen as the obvious crop of choice for wastewater phytoremediation (Rosenqvist et al., 1997; Hasselgren, 1998). Willow has also been shown to be resilient to polluting substances (Bialowiec et al., 2007; Bialowiec and Randerson, 2010) and so has the necessary rigorousness to cope with the wide ranging pollut ants in wast ewater. Studies on the use of willow as a means of treating/disposing wastewater effluent via evapotranspiration have shown rates up to $1790 \mathrm{~mm}$ being achieved over the course of a growing season under fertilised conditions (Gregersen and Brix, 2001; Martin and Stephens, 2006b; Guidi et al., 2008). It has also been seen that evapotranspiration is strongly correlated to plant development (Guidi et al., 2008; Pistocchi et al., 2009) and mainly dependent on its nutritional availability rather than on the differences between the varieties. A study on the effect of different strength fertilisers on the evapotranspiration from willow trees (Pistocchi et al., 2009) found 
evapotranspiration rates were 1.4-2 times greater for the plants irrigated with high compared to low strength effluent. Guidi et al. (2008) calculated crop coefficients varying from 0.6 up to 5.3 over the second growing season (May to October) whilst a study on willows irrigated with landfill leachate in Poland determined crop coefficients of $1.97-5.12$ during the growing season (Bialowiec et al., 2007). In Denmark, EPA guidelines have been developed (Miljøstyrelsen, 2003) for the design of zero discharge evapotranspiration systems to treat domestic wastewater using willows. The country has been divided into climatic areas from which the required area of willow plantation can be cal culated with respect to local annual rainfall and evapotranspiration conditions.

While previous studies in Scandinavian (Persson, 1995; Gregersen and Brix, 2001) and Mediterranean (Guidi et al., 2008; Pistocchi et al., 2009) conditions have produced evapotranspiration rates for willow plants under both fertilised and unfertilised conditions, no such figures are available for Irish climatic conditions - i.e. a maritime temperate climate with reasonably consistent rainfall throughout the year. Domestic wastewater from a single house in Ireland has high concentrations of both nitrogen and phosphorus (Gill et al., 2009; Gill, 2011) which should promote the continued growth of the trees in the zero discharge willow bed systems. Hence, a series of mesocosm lysimeter experiments on four different willow varieties was set up to assess the evapotranspiration rate between each variety under Irish meteorological conditions as well as the effect of different strength effluent on growth response and evapotranspiration. The results of these experiments have then been used to inform the design of the fullscale systems which are currently being trialled.

\section{Materials and methods}

\subsection{Experimental set up}

Cylindrical containers of height $1000 \mathrm{~mm}$ and diameter $540 \mathrm{~mm}$ were placed at an open site and filled with layers of gravel ( $75 \mathrm{~mm})$, sand $(440 \mathrm{~mm})$ and topsoil $(460 \mathrm{~mm})$. A $30 \mathrm{~mm}$ plastic inspection pipe (with $10 \mathrm{~mm}$ diameter holes at the bottom) was inserted into each container to enable water level measurement (Fig 1). Before

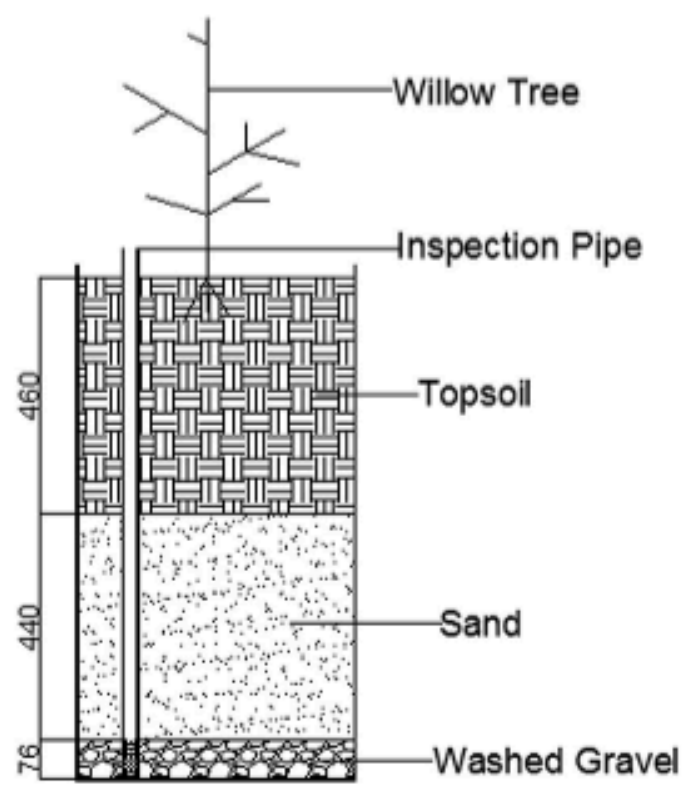

Fig. 1. Cross Sectional detail of mesocosm experiment. planting the willow trees, each container was calibrated in order to show the volume of water in the barrel with respect to increasing water depth. Three replicates of four willow varieties (supplied by Rural Generation Limited, Londonderry, Northern Ireland) were then planted one plant per container. The willow varieties used Tordis, Sven, Inger and Torhild, are all cultivars of Salix viminalis L. as follows: Tordis $[($ Salix schwerinii E. L. Wolf. $\times$ S. viminalis $\mathrm{L}) \times \mathrm{S}$. viminalis L.]; Sven (Salix viminalis L. $\times$ S. schwerinii E. L. Wolf.); Inger (Salix triandra L. $\times$ S. viminalis L.); and Torhild [(Salix schwerinii E.L. Wolf. $\times$ S. viminalis L.) $\times$ S. viminalis L.] (Caslin et al., 2012). The willows were planted as $30 \mathrm{~cm}$ cuttings in June 2009. Each plant variety was then given an application of primary (septic tank) effluent $(P)$, secondary treated effluent $(S)$ and rain water $(W)$ (as a control) (Section 2.3). The dosage for all containers (including the control containers) was $2.2 \mathrm{~L}$ per week (i.e. $9.6 \mathrm{~mm}$ per week) which equated to the approximate areal hydraulic loading rate that one willow tree would receive in a full-scale willow bed, on the basis of assumed on-site wastewater production in Ireland of $150 \mathrm{~L}$ per capita per day (EPA, 2009). All containers were open and so also received the local natural rainfall.

\subsection{Water balance}

An accurate mass balance of elements entering and leaving the systems required a rigorous assessment of the water budget throughout the monitoring period on the basis of treatment inflows combined with local meteorological effects (rainfall and evapotranspiration (ET) rates) as detailed in equation (1).

$\mathrm{ET}_{\text {willow }}=I+R-E$

where, $\mathrm{ET}_{\text {willow }}=$ actual evapotranspiration $(\mathrm{mm}), I=$ Effluent/ Water applied (mm), $R=$ Rainfall (mm), $E=$ Drainage occurring $(\mathrm{mm})$ lassumed to be zero in these experiments since the mesocosms are in sealed containers].

A weather station (Campbell Scientific (CS), Leicestershire, U.K.) which measured rainfall (AGR100), temperature (CS 215), air humidity (CS 215), net radiation (NR-Lite, Kipp and Zonen) and wind speed and direction (03002, R.M. Young) was erected in close proximity to the containers. The reference evapotranspiration $\left(\mathrm{ET}_{0}\right)$ was calculated from the collected meteorological data using the modified Penman-Monteith equation (FAO, 1998). The water level in each container was measured at regular time intervals over three growing seasons, from which the corresponding volume was obtained. The actual evapotranspiration from each container for any particular time interval was then calculated using a water balance equation (Eqn. (1)), taking into account the additional volume of rainfall onto each surface area. The values obtained for actual evapotranspiration were then compared with the reference evapotranspiration to calculate a crop coefficient. Suitable seasondependent crop coefficients $(K c)$ were established in order to estimate the evapotranspiration related to the willow system ( $\mathrm{ET}_{\text {wil- }}$ low), as per equation (2):

$\mathrm{ET}_{\text {willow }}=K_{c} \mathrm{ET}$ 。

where, ETo is the reference evapotranspiration

The values for each variety and treatment were compared in order to determine the most efficient variety and the optimum treatment type.

\subsection{Water sampling and analysis}

The recipes for the synthetic effluent were based upon recipes by Peeples and Mancl (1998) but then adjusted so the effluent 
Table 1

Effluent concentrations and quantities.

\begin{tabular}{|c|c|c|c|c|c|c|}
\hline \multirow[t]{2}{*}{ Parameter } & \multicolumn{3}{|l|}{ Primary treatment } & \multicolumn{3}{|l|}{ Secondary treatment } \\
\hline & Average value (mg/l) & StDev $(\mathrm{mg} / \mathrm{l})$ & Total added ${ }^{2}(\mathrm{~g})$ & Average value (mg/l) & StDev $(\mathrm{mg} / 1)$ & Total Added' (g) \\
\hline COD & 849.5 & 104.5 & 100.9 & 261.4 & 140.8 & 31.1 \\
\hline Nitrate (as N) & 1.0 & 0.1 & 0.12 & 38.9 & 6.1 & 4.62 \\
\hline Chloride & 159.9 & 24.8 & 19.0 & 81.4 & 19.43 & 9.67 \\
\hline Ammonia (as N) & 59.1 & 8.3 & 7.02 & 19.9 & 10.7 & 2.36 \\
\hline Total Nitrogen (as N) & 163.2 & 49.7 & 19.4 & 80.5 & 18.6 & 9.56 \\
\hline Ortho-phosphate (as P) & 13.9 & 6.9 & 1.65 & 9.52 & 5.22 & 1.13 \\
\hline Total-phosphate (as P) & 13.24 & 0.11 & 1.57 & 8.93 & 0.354 & 1.06 \\
\hline Potassium (as K) & 22.6 & 0 & 2.68 & 17.61 & 1.032 & 2.09 \\
\hline
\end{tabular}

a Total amount of each parameter added to each barrel over three seasons.

reflected the concentrations more usually found in Irish septic tank (i.e. primary treated) and secondary treated on-site effluent (Gill, 2011). Each ingredient was weighed on a scale, mixed together and then the effluents were made up every week to the required volume for application to the willow varieties (i.e. $9.6 \mathrm{~mm}$ per week). The treatments were added 20 times over the course of the 2010 growing season, totalling $192 \mathrm{~mm}, 18$ times over the 2011 season totalling $173 \mathrm{~mm}$ and 16 times over the 2012 season totalling $144 \mathrm{~mm}$. The rain water for the control containers was collected from runoff from glass-house roof adjacent on the site of the trials. During periods of high evapotranspiration it was occasionally necessary to add extra water to some of the containers to prevent them drying out and so ensure that there was always available water in the containers for the willows to continue at their maximum evapotranspiration rate. The concentrations of the main parameters along with total amount of each added over the three seasons can be seen in Table 1.

\subsection{Plant biomass and soil analysis}

At end of the second growing season all trees were coppiced in order to quantify the level of nutrient and organic uptake by the trees. The height, diameter of the main stem and the dried biomass weight were measured. The main stem, side shoots and leaves for each plant were then separated and cut into $2 \mathrm{~cm}$ segment samples. All parts were then thoroughly washed in distilled water to remove any sediment or biofilm which may have compromised the sample. The respective stems, side shoots and leaves for each experiment were then labelled and dried in a forced air oven for 3 days at $105^{\circ} \mathrm{C}$ (until the weight remained constant). Once dry, the respective biomass samples were then weighed. Each sample was then ground down to a fine dust using a mill (Retsch Planetary Ball Mill PM 100, Haan, Germany). The total phosphorus (TP) and potassium extraction was carried out using the acid digestion method as per Standard Methods (APHA, 1998) as follows. $0.3 \mathrm{~g}$ of sample was added to $10 \mathrm{~mL}$ of nitric acid and $2 \mathrm{~mL}$ of sulphuric acid. The mixture was placed in a vessel and then microwaved for $2 \mathrm{~h}$ in a microwave (Multiwave PRO microwaved reaction system). The mixture was then al lowed to cool overnight, before being made up to $50 \mathrm{~mL}$ with distilled water. The total phosphorus and potassium concentrations were subsequently measured in an ICP (Inductively Coupled Plasma) machine (Varian, Liberty AX Series II ICP-AES, Santa $\mathrm{Clara}, \mathrm{CA}$ ) following calibration against standards over $0.5-$ $100 \mathrm{mg} \mathrm{L}^{-1}$ range.

The total nitrogen (TN) and total organic carbon (TOC) values were determined by weighing samples of $5 \mathrm{mg}$ on a 4 -figure micro

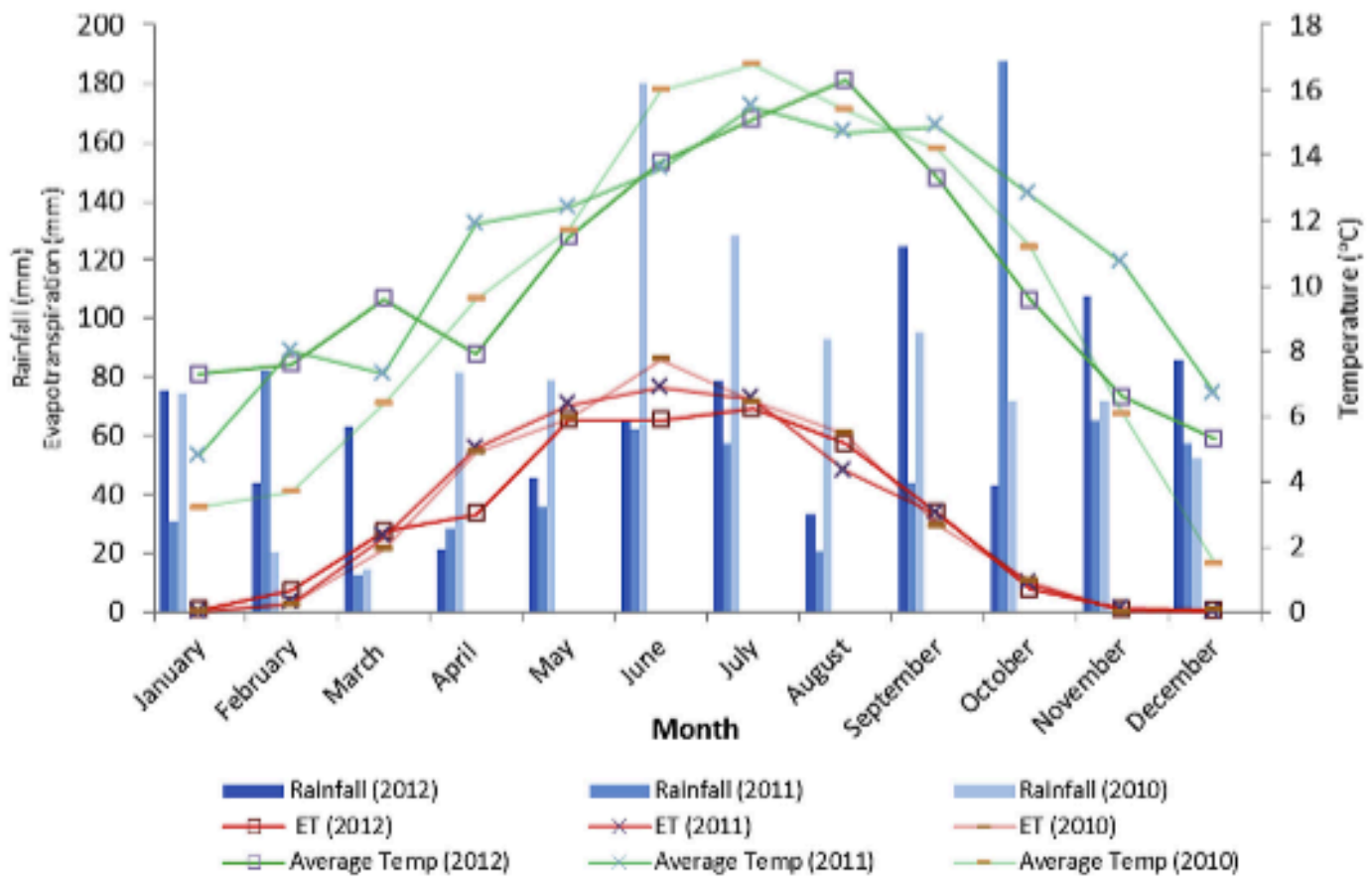

Fig. 2. Monthly meteorological data for 2010/11/12. 
balance (Cahn, Beverley, MA) and then wrapping them in foil. The samples were then placed in the Elementar vario EL Cube (Hanau, Germany) which had been calibrated against fixed standards, where they were subjected to high temperature combustion, with detection carried out using thermal conductivity.

Representative soil samples were taken from each of the containers before the trials had started and effluent applied. The samples were weighed and then dried in a forced air oven for 3 days at $105^{\circ} \mathrm{C}$ (until the weight remained constant). They were ground down to a fine dust and analysed in the same manner as the biomass (see previous) for total nitrogen, total organic carbon, total phosphorus and potassium.

\subsection{Statistical analysis}

The experiment consisted of a $4 \times 3$ factorial design using the 2 factors, willow variety and treatment type. All parameters measured were expressed as a mean and referred to the individual container. All data was subjected to a two-way analysis of variance (ANOVA) to statistically test the effects of variety and treatment type on evapotranspiration and nutrient absorption. The analysis was carried out on the Minitab statistical software package (Minitab Inc., USA), LSD (Least Significant Difference) test ( $p \leq 0.05$ by convention (Agresti, 1996)) was used to identify significant differences.

\section{Results}

\subsection{Climate}

The average monthly weather data along with the monthly $\mathrm{ET}_{0}$ at the site location for the 2010, 2011 and 2012 growing seasons are shown in Fig. 2. In general, the climatic data over the three growing seasons were similar with a few notable exceptions. Although not
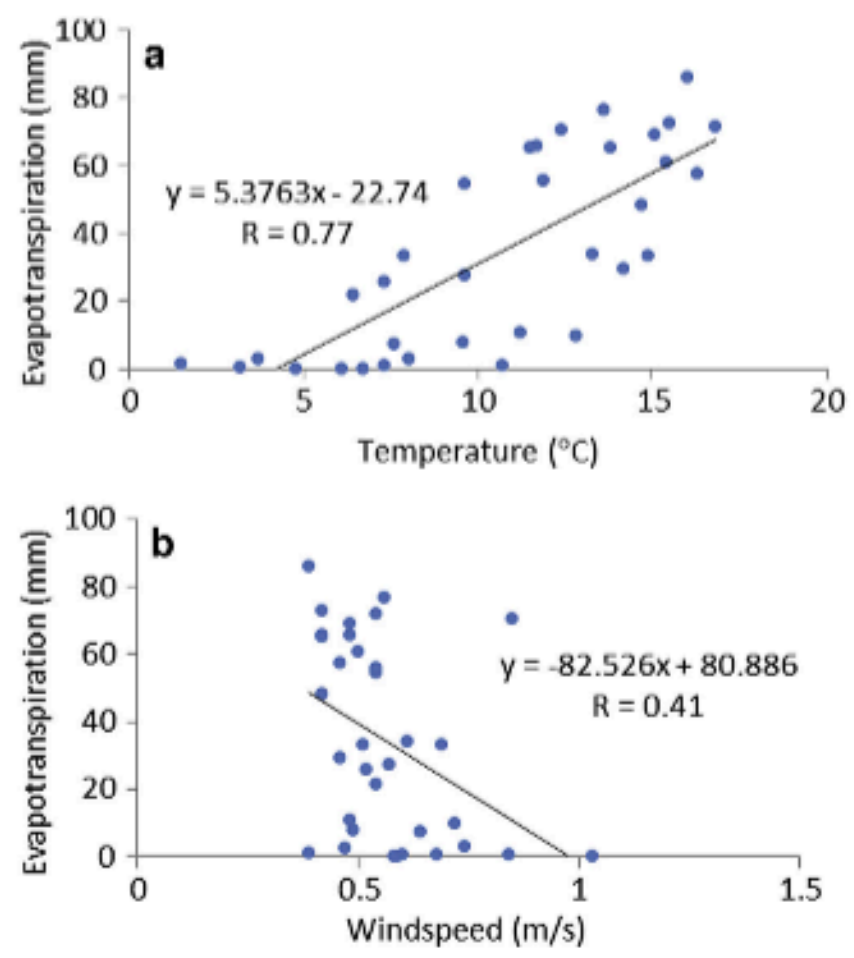

Fig. 3. Correlation between monthly average ET and (a) temperature and (b) wind speed.

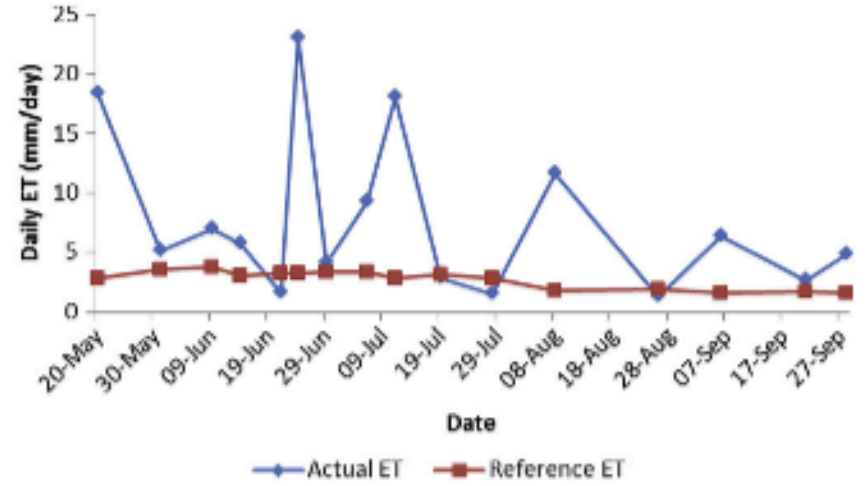

Fig. 4. Reference ET and measured ET over the 2011 growing season for Sven.

significantly different $(p=0.235)$, the average temperature during June and July of 2010 was noticeably higher than the following two years which also promoted higher evapotranspiration, especially in the month of June. It should also be noticed that the 2012 growing
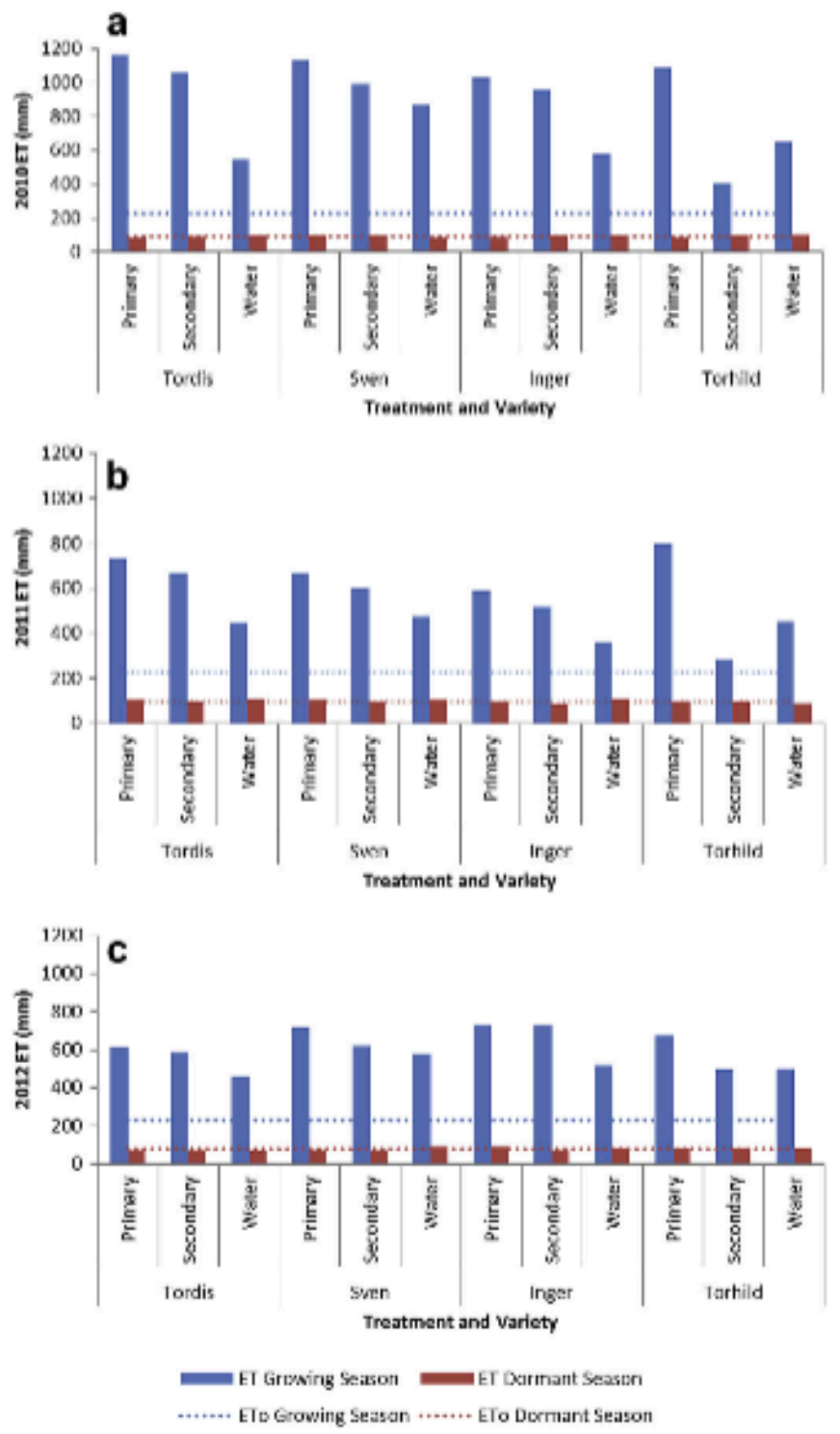

Fig. 5. Actual ET and reference ET for (a) 2010, (b) 2011 and (c) 2012 growing seasans. 
Table 2

Evapotranspiration rates $\left(\mathrm{mm}^{\mathrm{day}}{ }^{-1}\right)$ for different effluent treatments and willow varieties during the 2010, 2011 and 2012 growing seasons.

\begin{tabular}{llllll}
\hline Year & Treatment & \multicolumn{4}{l}{ Variety } \\
\cline { 3 - 6 } & & Tordis & Sven & Inger & Torhild \\
\hline \multirow{2}{*}{2012} & Primary & $3.99 \pm 0.38$ & $4.69 \pm 0.31$ & $4.74 \pm 0.44$ & $4.39 \pm 0.27$ \\
& Secondary & $3.82 \pm 0.18$ & $4.07 \pm 0.42$ & $4.75 \pm 0.42$ & $3.26 \pm 0.18$ \\
\multirow{2}{*}{2011} & Water & $3.01 \pm 0.20$ & $3.78 \pm 0.46$ & $3.38 \pm 0.38$ & $3.26 \pm 0.25$ \\
& Primary & $4.80 \pm 0.39$ & $4.36 \pm 0.27$ & $3.86 \pm 0.36$ & $5.23 \pm 0.59$ \\
& Secondary & $4.35 \pm 0.24$ & $3.93 \pm 0.38$ & $3.38 \pm 0.37$ & $1.87 \pm 0.11$ \\
\multirow{2}{*}{2010} & Water & $2.91 \pm 0.39$ & $3.11 \pm 0.29$ & $2.37 \pm 0.14$ & $2.96 \pm 0.31$ \\
& Primary & $7.61 \pm 0.39$ & $7.38 \pm 0.93$ & $6.73 \pm 0.60$ & $7.10 \pm 0.30$ \\
& Secondary & $6.95 \pm 0.39$ & $6.50 \pm 0.50$ & $6.29 \pm 0.73$ & $2.68 \pm 0.07$ \\
& Water & $3.56 \pm 0.42$ & $5.67 \pm 0.37$ & $3.78 \pm 0.45$ & $4.29 \pm 0.29$ \\
\hline
\end{tabular}

season was unseasonably wet and cool with almost twice the normal precipitation falling during this period.

The total rainfall for each year was $788 \mathrm{~mm}$ (2010), $685 \mathrm{~mm}$ (2011) and $839 \mathrm{~mm}$ (2012), aver age temperature was $9.7^{\circ} \mathrm{C}(2010)$, $11.1{ }^{\circ} \mathrm{C}(2011)$ and $11.2{ }^{\circ} \mathrm{C}(2012)$ and total reference evapotranspiration $405 \mathrm{~mm}$ (2010), $396 \mathrm{~mm}$ (2011) and $368 \mathrm{~mm}$ (2012). Fig. 3(a) shows the correlation (Pearson $r$-value of 0.77 ) between the air temperature and the reference evapotranspiration. However, there was little correlation (Pearson $r$-value of 0.41 ) between the mean wind speed and the reference evapotranspiration [Fig. 3(b)] which indicates the independence of wind speed with respect to different seasons in such a maritime temperate climate.

\subsection{Water balance (evapotranspiration and crop coefficients)}

An example of the net evapotranspiration across the summer period from one of the willow varieties (Sven) in its first growing season (2010) receiving septic tank effluent is shown in Fig. 4. This shows a surprisingly varying dynamic with the ratio between the reference evapotranspiration and measured evapotranspiration, the crop coefficient, for this particular variety fluctuating between 0.5 and 6.9 during the summer months.

The measured evapotranspiration values along with the $\mathrm{ET}_{0}$ baseline for each barrel for the three years can be seen in Figs. 5(a), (b) and (c), with the corresponding evapotranspiration rates listed in Table 2 and corresponding crop coefficients in Table 3. The general pattern for all seasons was similar, with the clones receiving primary effluent having the highest evapotranspiration, followed by the clones receiving secondary effluent with the clones receiving water having the lowest evapotranspiration (although there was only a significant difference between the trees receiving primary treated effluent and those receiving rain water: $p=0.001$ ) but the actual evapotranspiration values in 2011 and 2012 were much lower $(p=0.0)$ than those obtained in 2010. Table 4 summarises the performance of the trials with respect to effluent type and variety.

Over the 2010 growing season [Fig. 5(a)] it was observed that the trees applied with primary treated effluent had slightly higher evapotranspiration (mean $=7.21 \mathrm{~mm} \mathrm{~d}^{-1}$ ) compared to the trees receiving secondary treated effluent (mean $=5.61 \mathrm{~mm} \mathrm{~d}^{-1}$ ) and both of these outperformed the trees receiving just rain water (mean $=4.32 \mathrm{~mm} \mathrm{~d}^{-1}$ ) (i.e. neither primary nor secondary effluent). While there was no statistical difference between trees receiving primary and secondary treated effluent $(p=0.162)$ or trees receiving secondary treated effluent and rain water $(p=0.286)$, there was a statistical difference between trees receiving primary treated effluent and those receiving rain water $(p=0.001)$. However, one variety, Torhild, revealed a different trend with very low evapotranspiration measured from the containers receiving secondary treated effluent. During the dormant season the actual evapotranspiration remained relatively close $(p=0.089)$ to the reference evapotranspiration for all varieties, regardless of effluent type, as might be expected for a saturated soil.

The 2011 growing season [Fig. 5(b)] resulted in much lower $(p=0.001)$ evapotranspiration values but the pattern of the fertilised trees outperforming the controls remained. Again, the trees under primary treated effluent had slightly higher ET values ( mean $=4.56 \mathrm{~mm} \mathrm{~d}^{-1}$ ) compared to the trees receiving secondary treated effluent (mean $=3.38 \mathrm{~mm} \mathrm{~d}^{-1}$ ) and both these outperformed the trees receiving water treatment (mean $=2.83 \mathrm{~mm} \mathrm{~d}^{-1}$ ) with the exception again of the Torhild variety receiving secondary treated effluent. While there was no statistical difference between trees receiving primary and secondary treated effluent $(p=0.104)$ or trees receiving secondary treated effluent and rain water $(p=0.37)$, there was a statistical difference between trees receiving primary treated effluent and those receiving rain water $(p=0.002)$. Again, as per the previous year, the actual evapotranspiration during the dormant season remained close $(p=0.077)$ to the reference evapotranspiration for all varieties.

The evapotranspiration rates remained low for the 2012 growing season [Fig. 5(c)], with similar values $(p=0.34)$ to the 2011 season. The fertilised trees outperformed their water receiving counterparts again. The values were slightly lower for varieties receiving secondary treated effluent (mean $=3.98 \mathrm{~mm} \mathrm{~d}^{-1}$ ) than the varieties receiving primary treated effluent ( mean $=4.45 \mathrm{~mm} \mathrm{~d}^{-1}$ ), but both were higher than the ET rates for the varieties receiving only water $\left(\right.$ mean $=3.36 \mathrm{~mm} \mathrm{~d}^{-1}$ ). There was no statistical difference between trees receiving primary and secondary treated effluent $(p=0.296)$ or trees receiving secondary treated effluent and rain water $(p=0.843)$, there was a statistical difference between trees receiving primary treated effluent and those receiving rain water $(p=0.012)$. It should be noted that the

Table 3

Crop Coefficients, $K$ for different effluent treatments and willow varieties.

\begin{tabular}{|c|c|c|c|c|c|c|c|c|c|}
\hline \multirow[t]{3}{*}{ Year } & \multirow[t]{3}{*}{ Treatment } & \multicolumn{4}{|c|}{ Growing season } & \multicolumn{4}{|c|}{ Dormant season } \\
\hline & & \multicolumn{8}{|l|}{ Variety } \\
\hline & & Tord is & Sven & Inger & Torhild & Tord is & Sven & Inger & Torhild \\
\hline \multirow[t]{3}{*}{2012} & Primary & $2.54 \pm 0.24$ & $2.98 \pm 0.19$ & $3.01 \pm 0.28$ & $2.79 \pm 0.17$ & $0.94 \pm 0.11$ & $0.98 \pm 0.08$ & $1.15 \pm 0.09$ & $1.11 \pm 0.10$ \\
\hline & Secondary & $2.43 \pm 0.12$ & $2.59 \pm 0.27$ & $3.02 \pm 0.27$ & $2.06 \pm 0.11$ & $0.95 \pm 0.07$ & $0.93 \pm 0.11$ & $0.92 \pm 0.09$ & $1.06 \pm 0.08$ \\
\hline & Water & $1.91 \pm 0.13$ & $2.41 \pm 0.29$ & $2.15 \pm 0.24$ & $2.07 \pm 0.16$ & $0.91 \pm 0.09$ & $1.14 \pm 0.07$ & $1.07 \pm 0.12$ & $1.04 \pm 0.07$ \\
\hline \multirow[t]{3}{*}{2011} & Primary & $3.53 \pm 0.29$ & $3.2 \pm 0.20$ & $2.84 \pm 0.26$ & $3.85 \pm 0.43$ & $1.10 \pm 0.12$ & $1.07 \pm 0.11$ & $1.04 \pm 0.06$ & $1.04 \pm 0.10$ \\
\hline & Secondary & $3.10 \pm 0.17$ & $2.90 \pm 0.28$ & $2.49 \pm 0.27$ & $1.38 \pm 0.08$ & $1.01 \pm 0.08$ & $1.02 \pm 0.13$ & $0.91 \pm 0.10$ & $1.00 \pm 0.11$ \\
\hline & Water & $2.14 \pm 0.28$ & $2.29 \pm 0.22$ & $1.74 \pm 0.10$ & $2.18 \pm 0.22$ & $1.13 \pm 0.13$ & $1.07 \pm 0.07$ & $1.12 \pm 0.07$ & $0.93 \pm 0.12$ \\
\hline \multirow[t]{3}{*}{2010} & Primary & $5.1 \pm 0.26$ & $4.93 \pm 0.62$ & $4.5 \pm 0.40$ & $4.75 \pm 0.20$ & $0.96 \pm 0.10$ & $1.04 \pm 0.14$ & $1.02 \pm 0.08$ & $0.94 \pm 0.11$ \\
\hline & Secondary & $4.64 \pm 0.26$ & $4.34 \pm 0.34$ & $4.2 \pm 0.49$ & $1.79 \pm 0.04$ & $1.01 \pm 0.05$ & $1.09 \pm 0.10$ & $1.09 \pm 0.06$ & $1.15 \pm 0.12$ \\
\hline & Water & $2.38 \pm 0.28$ & $3.78 \pm 0.25$ & $2.53 \pm 0.30$ & $2.86 \pm 0.19$ & $1.06 \pm 0.12$ & $0.95 \pm 0.12$ & $1.11 \pm 0.12$ & $1.13 \pm 0.07$ \\
\hline
\end{tabular}


Table 4

Effect of different treatments and varieties on ET ( $\mathrm{mm}$ ).

\begin{tabular}{|c|c|c|c|c|c|c|c|c|c|}
\hline \multirow[t]{3}{*}{ Year } & \multicolumn{7}{|c|}{ ET means (mm) } & \multirow{2}{*}{\multicolumn{2}{|c|}{$\frac{\text { Significance }}{p}$}} \\
\hline & \multicolumn{3}{|c|}{ Treatment } & \multicolumn{4}{|l|}{ Variety } & & \\
\hline & Primary & Secondary & Water & Tordis & Sven & Inger & Torhild & Treatment & Variety \\
\hline 2012 & 681 & 607 & 514 & 552 & 639 & 656 & 555 & 0.011 & 0.096 \\
\hline 2011 & 698 & 518 & 434 & 615 & 582 & 490 & 513 & 0.048 & 0.571 \\
\hline 2010 & 1103 & 858 & 661 & 924 & 997 & 857 & 718 & 0.046 & 0.397 \\
\hline
\end{tabular}

a $p<0.05$ denotes a statistically significant relationship.

poorly performing Torhild cultivars receiving secondary effluent, while still having a lower ET rate compared to the other cultivars under the same effluent applications, did improve in 2012 relative the other Torhild willows receiving primary effluent and water applications.

The crop coefficients, $K_{c}$ followed the same pattern as the ET rates (see Table 3 ). The 2010 growing season provided the highest $K_{c}$ values, varying from 4.5 to 5.1 (mean: 4.82 ) for the cultivars receiving primary treated effluent. This decreased to 1.79 to 4.64 (mean: 3.74) for the cultivars receiving secondary treated effluent. The values dropped further for the cultivars receiving water treatment; $2.38-3.78$ (mean: 2.89 ).

The crop coefficient values for the 2011 growing season were as follows; cultivars receiving primary treated effluent: 2.84 to 3.85 (mean: 3.36), cultivars receiving secondary treated effluent: 1.38 to 3.1 (mean: 2.47 ) and cultivars receiving water treatment: 1.74 to 2.14 (mean: 2.09).

The crop coefficient values for the 2012 growing season were as follows; Cultivars receiving primary treated effluent: 2.54 to 3.01 (mean: 2.83 ), cultivars receiving secondary treated effluent: 2.43 to 3.02 (mean: 2.53) and cultivars receiving water treatment: 1.91 to 2.41 (mean: 2.14).

\subsection{Biomass}

The physical properties of the willow plants after the first and third growing seasons can be seen in Fig. $6(\mathrm{a})$ and Fig. $6(\mathrm{~b})$. In the first growing season the heights of the main stem of each plant varied from $3.0 \mathrm{~m}$ to $4.7 \mathrm{~m}$ with the irrigated effluent type not having any significant effect on the height $(p=0.196)$. The heights of the stems varied between $3.1 \mathrm{~m}$ and $4.7 \mathrm{~m}$ at the end of the $3 \mathrm{rd}$ growing season with treatment type again having no effect on the heights $(p=0.660)$. The variety type did have a significant effect on stem height in the first season $(p=0.003)$ but not in the third season $(p=0.922)$. The diameter of the main stems ranged from $24 \mathrm{~mm}$ to $36.5 \mathrm{~mm}$ for the first season and again, al though effluent quality did show some correlation it was not significant at the $95 \%$ level $(p=0.060)$. In the 3rd growing season the stem diameters ranged from $16 \mathrm{~mm}$ to $29 \mathrm{~mm}$, with treatment type have no significant effect on values ( $p=0.395)$. The variety type had no significant effect on stem diameters in either the first or third seasons $(p=0.056, p=0.778)$. The dry weight of the biomass recovered from each mesocosm container at the end of the first season ranged from $228 \mathrm{~g}$ to $863 \mathrm{~g}$ and the effluent quality did have a significant effect on these values $(p=0.019)$ as shown in Table 5 . The average biomass dry weight for the trees receiving primary treated effluent was $728 \mathrm{~g}$ which decreased to $544 \mathrm{~g}$ for the trees receiving secondary treated effluent and $372 \mathrm{~g}$ for the trees receiving water. Although the treatment type did not have a significant effect $(p=0.233$ ) on the dry weight of the biomass recovered from the willows at the end of the third growing season, there still remained a pattern quite similar to that of the first growing season, with greater biomass produced for the more concentrated effluent received. The dry weight of the biomass for the willows coppiced at the end of the third season ranged from $250 \mathrm{~g}$ to $1599 \mathrm{~g}$. The average biomass dry weight of trees receiving primary effluent was $1,243 \mathrm{~g}, 875 \mathrm{~g}$ for trees receiving secondary effluent and $802 \mathrm{~g}$ for trees receiving water. As with the stem diameter, the variety type had no significant effect on the dry weight of the willow biomass in either the first or third season $(p=0.119, p=0.928$ ).

The total nitrogen, total organic carbon, phosphorus and potassium in the original soil as well as irrigated onto the respective plants up until first coppicing is shown in Table 6. This shows that the amount of nutrients supplied in the irrigated effluents is relatively small compared to the quantities al ready existing in the soil in each container.

It should be noted that there were small variations in the amount of compounds added to each plant due to the extra water that was added to some containers which were low in available water due to high evapotranspiration at that particular time.

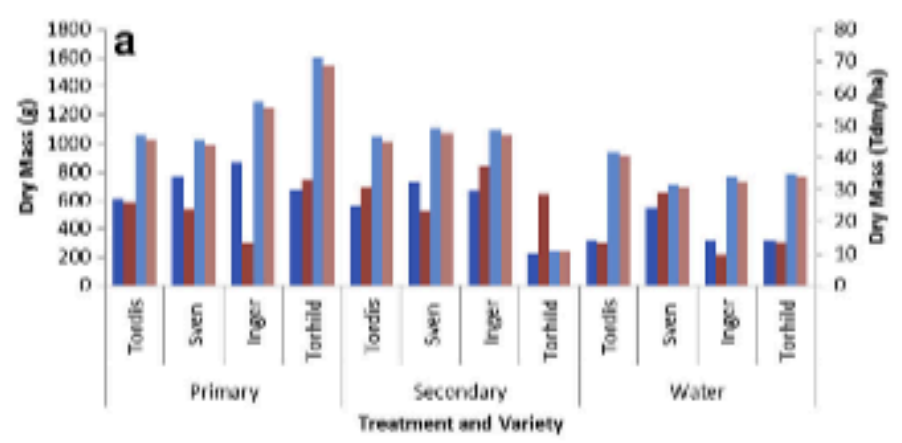

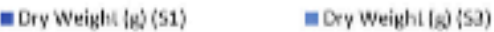
E Dry Weight [Tdrnhal [s1] =Dry Weight [idrvita) (sa)

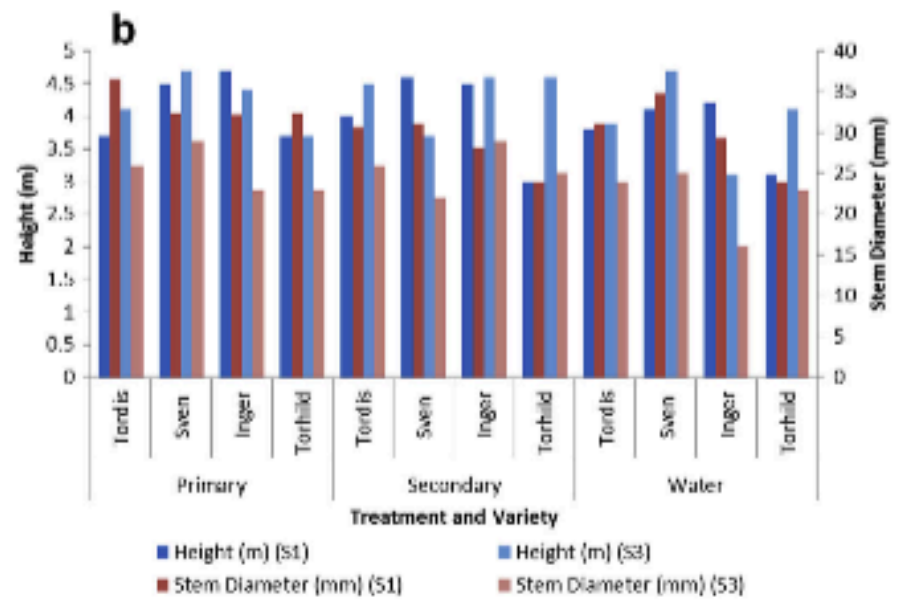

Fig. 6. Biomass growth willows coppiced at end of Season 1 and Season 3 as determined by (a) dry mass and (b) height and stem diameter of willows. 
Table 5

Effect of treatment and variety on physical parameters.

\begin{tabular}{llllll}
\hline Parameter & \multicolumn{2}{l}{ p-value } & & \\
\cline { 2 - 3 } & \multicolumn{2}{l}{ Season 1 } & & & \multicolumn{2}{l}{ Season 3 } \\
\cline { 2 - 3 } \cline { 5 - 6 } & Variety & Treatment & & Variety & Treatment \\
\hline Dry mass $(\mathrm{g})$ & 0.119 & 0.019 & & 0.928 & 0.233 \\
Height $(\mathrm{cm})$ & 0.003 & 0.196 & & 0.922 & 0.660 \\
Stem Diameter $(\mathrm{mm})$ & 0.056 & 0.060 & & 0.778 & 0.395 \\
\hline
\end{tabular}

The uptake of compounds by each plant can be seen in Table 7 . The average uptake of compounds by plants receiving primary treated effluent was $194.4 \mathrm{~kg}-\mathrm{N} \mathrm{ha}^{-1}, 13,543 \mathrm{~kg}^{-T O C} \mathrm{ha}^{-1}, 31.7 \mathrm{~kg}-$ $\mathrm{P} \mathrm{ha}^{-1}$ and $24.3 \mathrm{~kg}-\mathrm{K} \mathrm{ha}^{-1}$. The average uptake by plants receiving secondary treated effluent was $184.3 \mathrm{~kg}-\mathrm{N} \mathrm{ha}{ }^{-1}, 10,078 \mathrm{~kg}-$ TOC ha ${ }^{-1}, 27.2 \mathrm{~kg}-\mathrm{Pha}^{-1}$ and $12.4 \mathrm{~kg}-\mathrm{Kha}^{-1}$. The average uptake by the plants receiving water treatment was $94.6 \mathrm{~kg}-\mathrm{N} \mathrm{ha}^{-1}, 6980 \mathrm{~kg}-$ TOC ha ${ }^{-1}, 14.3 \mathrm{~kg}-\mathrm{P} \mathrm{ha}^{-1}$ and $12.4 \mathrm{~kg}-\mathrm{K} \mathrm{ha}^{-1}$.

Statistical analysis between the effect of variety and treatment on nutrient uptake revealed no significant difference $(p>0.05)$ between varieties but significant difference attributed to treatment type for nitrogen $(p=0.018)$, phosphorus $(p=0.015)$, potassium $(p=0.016)$ and TOC $(p=0.019)$. The uptake of compounds for each plant in comparison to the amounts added via the treatment is shown in Fig 7. Where the uptake exceeds the amount of compound added (for example, the willows receiving just irrigated water as well as P uptake for both primary and secondary effluent dosed varieties), the extra required nutrients were assumed to have been taken from the original soil.

\section{Discussion}

As can be seen from Fig. 5(a), (b) and (c) there was no discernible difference in the ETwillow rates between the four willow varieties, with the exception of the Torhild being applied with secondary treated effluent. However, the Torhild cultivars receiving secondary effluent visually had obvious growth and development defects for the first two years of growth, which had a knock-on effect on the

Table 6

Total compounds available to plants.

\begin{tabular}{|c|c|c|c|c|c|c|c|}
\hline \multirow[t]{3}{*}{ Variety } & \multirow[t]{3}{*}{ Parameter } & \multicolumn{6}{|c|}{ Nutrients available (kg/ha) } \\
\hline & & \multicolumn{2}{|l|}{ Source } & \multicolumn{2}{|l|}{ Source } & \multicolumn{2}{|l|}{ Source } \\
\hline & & Primary & Soil & Secondary & Soil & Watere & Soil \\
\hline \multirow[t]{4}{*}{ Tordis } & Nitrogen & 293.5 & 6242 & 146.7 & 6337 & 1.75 & 6810 \\
\hline & $\mathrm{TOC}^{-1}$ & 675.4 & 50508 & 261.6 & 51283 & 5.3 & 55100 \\
\hline & Phosphorus & 23.3 & 1950 & 15.7 & 1979 & $\mathrm{NA}^{\mathrm{b}}$ & 2127 \\
\hline & Potassium & 45.0 & 482 & 35.2 & 489 & 1.5 & 526 \\
\hline \multirow[t]{4}{*}{ Sven } & Nitrogen & 293.1 & 6337 & 146.2 & 6432 & 4.98 & 5770 \\
\hline & TOC & 674.3 & 51294 & 263.8 & 52039 & 15.1 & 46682 \\
\hline & Phosphorus & 23.3 & 1979 & 15.7 & 2009 & NA & 1802 \\
\hline & Potassium & 44.7 & 489 & 34.8 & 497 & 4.2 & 445 \\
\hline \multirow[t]{4}{*}{ Inger } & Nitrogen & 292.1 & 6337 & 146.2 & 6243 & 2.16 & 7094 \\
\hline & TOC & 671.1 & 51273 & 260.2 & 50508 & 6.5 & 57396 \\
\hline & Phosphorus & 23.3 & 1979 & 15.7 & 1950 & NA & 2216 \\
\hline & Potassium & 43.8 & 489 & 34.8 & 482 & 1.8 & 548 \\
\hline \multirow[t]{4}{*}{ Tomild } & Nitrogen & 292.4 & 6621 & 141.9 & 6810 & 2.74 & 5864 \\
\hline & TOC & 672.1 & 53569 & 247.1 & 55100 & 8.3 & 47447 \\
\hline & Phosphorus & 23.3 & 511 & 15.7 & 526 & NA & 453 \\
\hline & Potassium & 44.1 & 1145 & 31.2 & 1178 & 2.3 & 1014 \\
\hline
\end{tabular}

Table 7

Nutrient content in the plants.

\begin{tabular}{|c|c|c|c|c|}
\hline \multirow[t]{2}{*}{ Variety } & \multirow[t]{2}{*}{ Parameter } & \multicolumn{3}{|c|}{ Treatment } \\
\hline & & Primary & Secondary & Water \\
\hline \multirow[t]{4}{*}{ Tordis } & Nitrogen ( $\mathrm{kg} / \mathrm{ha})$ & 177.6 & 158.1 & 97.6 \\
\hline & $\mathrm{TOC}(\mathrm{kg} / \mathrm{ha})$ & 11298 & 10275 & 5889 \\
\hline & Phosphorus ( $\mathrm{kg} / \mathrm{ha}$ ) & 27.8 & 25.2 & 13.3 \\
\hline & Potassium (kg/ha) & 20.6 & 18.3 & 10.4 \\
\hline \multirow{4}{*}{ Sven } & Nitrogen (kg/ha) & 213.0 & 262.4 & 101.4 \\
\hline & TOC $(\mathrm{kg} / \mathrm{ha})$ & 14227 & 13244 & 10272 \\
\hline & Phosphorus ( $\mathrm{kg} / \mathrm{ha}$ ) & 33.6 & 38.6 & 17.8 \\
\hline & Potassium (kg/ha) & 25.8 & 24.3 & 18.4 \\
\hline \multirow[t]{4}{*}{ Inger } & Nitrogen (kg/ha) & 228.4 & 232.7 & 97.2 \\
\hline & TOC $(\mathrm{kg} / \mathrm{ha})$ & 16003 & 12518 & 5844 \\
\hline & Phosphorus (kg/ha) & 34.7 & 32.8 & 12.5 \\
\hline & Potassium (kg/ha) & 28.6 & 22.2 & 10.4 \\
\hline \multirow[t]{4}{*}{ Tomild } & Nitrogen (kg/ha) & 158.7 & 83.9 & 82.0 \\
\hline & TOC $(\mathrm{kg} / \mathrm{ha})$ & 12644 & 4275 & 5916 \\
\hline & Phosphorus ( $\mathrm{kg} / \mathrm{ha}$ ) & 30.7 & 12.3 & 13.6 \\
\hline & Potassium (kg/ha) & 22.1 & 7.6 & 10.3 \\
\hline
\end{tabular}

ETwillow rate and compound uptake for these trees. It is suspected that the initial cuttings must have been taken from the same original defective willow plant. Total $\mathrm{ET}_{\text {willow }}$ and $\mathrm{K}_{\text {willow }}$ for all three growing seasons appeared to be affected by the strength of effluent received (Table 4) with the varieties receiving primary treated effluent outperforming those receiving secondary treated effluent which in turn outperformed those receiving water. $\mathrm{ET}_{\text {willow }}$ rates for the varieties receiving primary effluent in the first season ranged between $1030 \mathrm{~mm}$ and $1165 \mathrm{~mm}$ (average $6.73-7.61 \mathrm{~mm}$ day ${ }^{-1}$ ) which compares similarly to the $\mathrm{ET}_{\text {willow }}$ obtained with fertilised willow (seasonal $\mathrm{ET}_{\text {willow }}$ of $1190 \mathrm{~mm}$ ) in Italy by Guidi et al. (2008). The $\mathrm{ET}_{\text {willow }}$ for the varieties receiving secondary effluent were slightly less $(410 \mathrm{~mm}-1064 \mathrm{~mm})$ but again also compared favourably. Equally, the varieties receiving water ( $\mathrm{ET}_{\text {wil- }}$ low rate ranging from $544 \mathrm{~mm}$ to $867 \mathrm{~mm}$ ) responded similarly to the non-fertilised willow in the Guidi et al. (2008) trials (seasonal $\mathrm{ET}_{\text {willow }}$ of $620 \mathrm{~mm}$ ). The $\mathrm{ET}_{\text {willow }}$ rates for the varieties receiving both primary and secondary treated effluent were slightly higher than the $870 \mathrm{~mm}$ obtained by Martin and Stephens (2006a, b) during the first season after coppice in research in a similar climate (UK) to Ireland's.

There was a noticeable decrease in ETwilbw rates for all varieties under all three treatments in the second and third years. This contrasted to the findings of Guidi et al. (2008) which showed an $\mathrm{ET}_{\text {willow }}$ rate increase of $50 \%$ for fertilised willow and $44 \%$ for unfertilised willow over the second growing season. It al so differs from Gregersen and Brix (2001) which saw similar increases in $\mathrm{ET}_{\text {willow }}$ rates from the first season to the second season. The reason for the measured decreases in the second and third years may have been due to cooler temperatures during the second and third growing seasons (on average $0.54{ }^{\circ} \mathrm{C}$ less) compared to the first growing season. From visual observation, the trees also appeared to be woodier and not have as much an abundance of leaves in the second and third growing seasons compared to the first season. As leaf area index is a critical factor in evapotranspiration (Persson, 1995; Running et al., 1989) this could have been an additional reason for the lower ET rates. It is also possible that the trees may have been inhibited due to the build-up of some contaminant in the containers over time, such as chloride.

The average crop coefficient, $K_{<}$for the willow varieties receiving primary effluent in $2010\left(K_{C}=4.82\right)$ is significantly higher than the values obtained by Guidi et al. (2008) (season $1 K_{\subset}$ of 1.61 and season $2 K_{c}$ of 2.97) and Pistocchi et al. (2009) (seasonal $K_{c}$ of 1.71) for willow cultivars under similar conditions. However, the varieties receiving secondary treated effluent performed similarly, with 

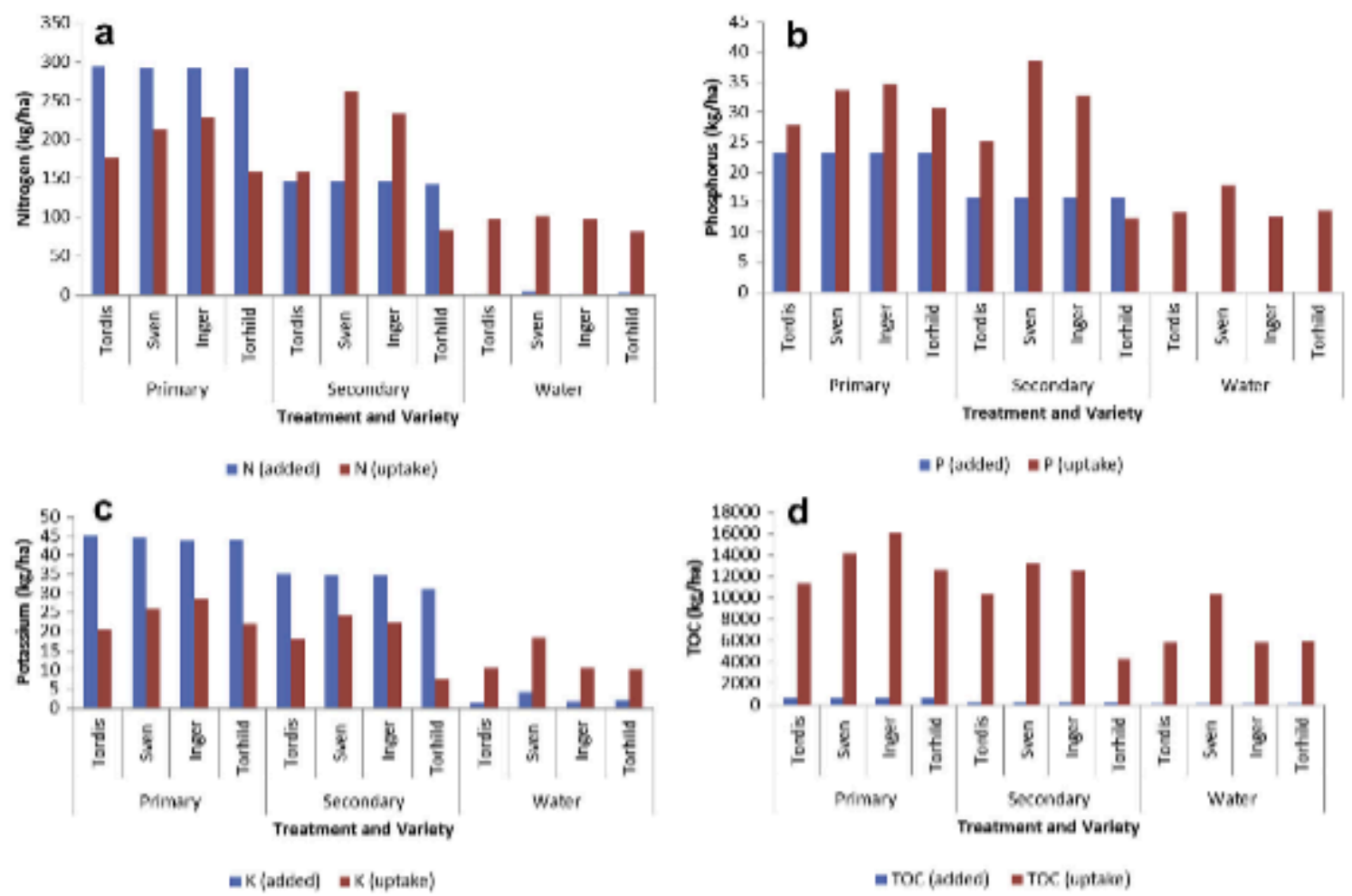

Fig 7. (a) Nitrogen, (b) phosphonus, (c) potassium and (d) TOC uptake by different willow varieties.

a mean $K_{c}$ of 3.74 for the season. The varieties receiving water treatment achieved a mean $K_{c}$ of 2.89 which is also much greater than the seasonal average $K_{c}$ obtained by Guidi et al. (2008) for non-fertilised willow cultivars (first season $K_{c}$ of 0.84 and second season $K_{c}$ of 1.47) which might be a result of the significant nutrient in the original soil in the experiments presented here. The $K_{c}$ values for the 2011 and 2012 were lower but still compared very favourably with results obtained by Guidi et al. (2008) and Pistocchi et al. (2009) for willows under similar treatment conditions. It should also be noted when comparing coefficients determined from different climatic areas that the calculation of the crop coefficient is strongly determined by the reference evapotranspiration at any site.

The uptake of organics and nutrients by the cultivars was affected by treatment type but not variety type. The cultivars receiving primary treated effluent were supplied with a relatively high amount of nitrogen (although similar to the amount applied by Dimitriou and Aronsson, 2011) compared to the recommended fertilisation rates for short rotation coppicing (SRC) willow in both Ireland ( $83 \mathrm{~kg}-\mathrm{N} \mathrm{ha}^{-1}$ ) (Caslin et al., 2010) and Sweden (80 kg$\mathrm{N} \mathrm{ha}^{-1}$ ) (Gustafsson and Larsson, 2007). The uptake of total nitrogen from these cultivars varied from $54 \%$ to $78 \%$ of the total nitrogen added (Fig. 7(a)). This is lower than the results obtained by Dimitriou and Aronsson (2011) where approximately 95\% of the total nitrogen applied was retained by the tree biomass. However, the uptake value of $194.4 \mathrm{~kg}-\mathrm{N} \mathrm{ha}{ }^{-1}$ from the cultivars receiving primary effluent is more comparable to that obtained by Aronsson and Bergstrom (2001) where willows supplied with $244 \mathrm{~kg}-\mathrm{N} \mathrm{ha}^{-1}$, showed a nitrogen uptake of $172 \mathrm{~kg}-\mathrm{N} \mathrm{ha}{ }^{-1}$ by the third growing season. For the plants receiving secondary treated effluent the retention increased to over $100 \%$ of total nitrogen added for three of the plants cultivars (although only $59 \%$ for the apparently struggling Torhild). The total amount absorbed (184.3 $\left.\mathrm{kg}^{-\mathrm{N}} \mathrm{ha}^{-1}\right)$ was only slightly lower than that for primary treated effluent. The uptake for the plants receiving water treatment is well over $100 \%$ in all cases, however, the overall amount absorbed is substantially lower $\left(94.6 \mathrm{~kg}-\mathrm{N} \mathrm{ha}^{-1}\right)$ than that for the willows receiving effluent. Again, it is assumed that the excess nitrogen was being taken from the soil, as discussed earlier.

The retention of phosphorus was over 100\% of total phosphorus added for all plants [Fig. 7(b)] except the Torhild receiving secondary effluent due to reasons explained previously. The retention values of $\geq 100 \%$ are in line with results obtained by Dimitriou and Aronsson (2011) and Sugiura et al. (2008) in which all of the applied phosphorus was retained by the willow plants. Hence, it might be surmised that phosphorus may well be the limiting nutrient for the growth and performance of such willow varieties receiving on-site effluent, although this cannot be confirmed from these experiments.

The uptake of total potassium from the plants receiving primary treated effluent varied from $46 \%$ to $65 \%$ of the total potassium added [Fig. 7(c)]. The $44 \mathrm{~kg}-\mathrm{K}$ ha ${ }^{-1}$ added via the primary treated effluent was almost exactly that recommended by Caslin et al. (2010) The uptake varies from $24 \%$ to $69 \%$ for the plants receiving secondary treated effluent and was over $100 \%$ for the plants receiving water treatment. The retention was slightly higher than that obtained by Larsson (2003) in which SRC willows receiving between 45 and $135 \mathrm{~kg}-\mathrm{K} \mathrm{ha}^{-1}$ achieved a maximum retention of $36 \%$.

The retention of TOC was emphatically greater than $100 \%$ of the TOC added via the treatments for all willow plants [Fig. 7(d)]. The $673.2 \mathrm{~kg}$-TOC ha-1 added through the primary treated effluent is similar to two levels (609 and $707 \mathrm{~kg}-\mathrm{TOC} \mathrm{ha}{ }^{-1}$ ) of treatment used by Dimitriou and Aronsson (2010). However, the results of this study were markedly better (compared to $84 \%$ retention in that investigation), with the TOC added only providing a small percentage of that taken up into the willow tree biomass (the rest assumed to have come from the soil). The $258.2 \mathrm{~kg}^{-T O C ~ h a-1}$ added through the secondary treated effluent is similar to the one of the levels (203 kg-TOC ha-1) of treatment added to willows in the same 


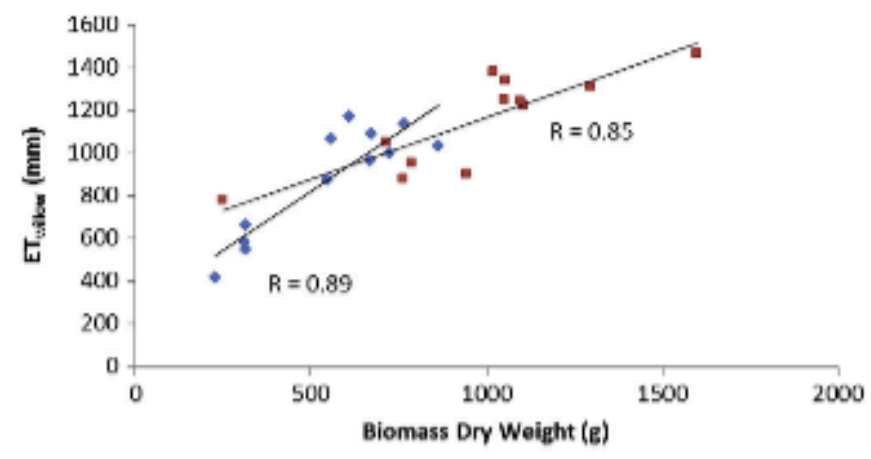

$+2010=2011 / 2012$

Fig. 8. Correlation between ET willow and biomass dry weight.

experiment by Dimitriou and Aronsson (2010). Again, while a good retention rate of $85 \%$ was achieved in that study, the uptake in this study was significantly greater.

The addition of effluent can be seen to have a significant effect on the dry weight of the biomass in the 1st season [Table 4 and Fig. 6(a)]. Although not statistically significant, this pattern continues for the 3rd season results [see Fig. 6(a)]. This compares similarly to the results of multiple examples of previous research (Martin and Stephens, 2006b; Guidi et al., 2008; Pistocchi et al., 2009).

As can be seen from Fig. 8, the 2010 and 2011/2012 growing seasons showed a strong correlation between biomass weight and evapotranspiration performance (Pearson's $R$ values of 0.89 and 0.85 respectively). This result matches with the findings of Martin and Stephens (2006a, 2006b). Hence, it can be deduced that there is a strong link between the strength of effluent added, to an increase of biomass and corresponding increase in the evapotranspiration rate in willows.

Finally, as can be seen from Table 6 the nutrients from the added effluents only made up a small proportion of the overall nutrients potentially available to the plants, with the soil providing the majority of the compounds. Yet, as discussed above, the addition of the effluent had a significant effect on the development and ET rates of the willows. It is therefore hypothesized that the apparent sensitivity of the willows to the strength of the effluent being applied was probably due to the nutrients in the effluent being in a soluble form which could be more preferentially taken up by the willow trees as opposed to the nutrients in the soil, most of which would be in a more particulate form.

\section{Conclusions}

These results from parallel mesocosm experiments have enabled realistic crop coefficients to be ascertained for four different willow varieties in Irish climatic conditions under simulated on-site effluent loadings. The willows have been shown to be capable of uptaking the levels of nutrients associated with domestic wastewater as well as having high enough evapotranspiration rates necessary for full-scale systems to function. On this basis, 10 fullscale evapotranspiration systems have been constructed to treat the wastewater effluent from single houses which cannot discharge their effluent to groundwater due to the very low permeability subsoils on the sites as an ongoing series of monitored pilot trials.

\section{Acknowledgements}

The research project is financed by Wexford County Council, Ireland.

\section{References}

APHA, 1998. Standard Methods for the Examination of Water and Wastewater, twentieth ed. American Public Health Association.

Aronsson, P.G. Bergstrom, LF, 2001. Nitrate leaching from lysimeter-grown shortrotation willow coppice in relation to $\mathrm{N}$-application, irrigation and soil type. Biomass Bioenergy 21, 155-164.

Agresti, A. 1996. Categorical Data Analysis. John Wiley \& Sons, Inc, Hoboken, NJ.

Beal, CD, Gardner, E.. Menzies, N.W. 2005. Process performance and pollution potential; a review of septic tank-soil absorption systems Aust. J. Soil Res. 43. $781-802$.

Bialowiec, A. Wojnowska-Baryla, L. Agppsowicz, M., 2007. The efficiency of evapotranspiration of landfill leachate in the soil-plant system with willow Salix amygadlina, L Ecol. Eng. 30, 356-361.

Biajowiec, A. Randerson, P. 2010. Zero Discharge Systems - a case study. In: CWA 6th Annual Conference, Wastewater Management and the Application of Constructed Wetlands Stoneleigh Park, Warwick, 22-24 June 2010.

Canter, L. Knox, R, 1985. Septic Tank System Effects on Ground water Quality. Lewis Publishers, Chelsea, MI.

Caslin, B. Finnan, J. McCracken, A. 2010. Short Rotation Coppice Willow Best Practice Guidelines. Teagasc, Ireland.

Caslin. B. Finnan. L McCradken. A. 2012. Willow Varietal Identification Guide, Teagasc, Ireland.

CSO, 2012. Census 2011, Principal Demographic Results. Central Statistics Office. Covernment of Ireland. Stationery Office, Dublin.

Dimitriou, L Aronsson. P. 2010. Landfill leachate treatment with willows and poplars - efficiency and plant response. Waste Manage. (Oxford) 30, 2137-2145.

Dimitriou, I. Aronsson, P. 2011. Wastewater and sewage sludge application to willows and poplars grown in lysimeter - plant response and treatment effciency. Biomass Bioenergy 35, 161-170.

EPA. 2009. Code of Practice: Wastewater Treatment and Disposal Systems Serving Single Houses. Environmental Protection Agency, Ireland.

FAO, 1998. Crop Evapotranspiration. Guidelines for Computing Crop Water Requirements. FMO Irrigation and Drainage Paper, 56. Food and Agricultural Organisation of the United Nations, Rome. Italy.

Gill LW O'Luanaigh. N Johnston. P. M, Misstear, B.D.R. O'Suilleabhain. C 2009, Nutrient loading on subsoils from on-site wastewater effluent, comparing septic tank and secondary treatment systems. Water Res 43, 2739-2749.

Gill, L.W. 2011. The development of a code of practice for single house on-site wastewater treatment in Ireland. Water Sci. Technol. 64 (3) 677-683.

Gregersen, P. Brix, H 2001. Zero-discharge of nutrients and water in a willow dominated constructed wethand. Water Sci. Technol. 44, 407-412.

Guidi. W. Piccioni, E. Bonari, E, 2008. Evapotranspiration and crop coefficient of poplar and willow short-rotation coppice used as vegetation filter. Bioresour. Technol. 99, 4832-4840.

Gustafsson, J Larsson, S, 2007. Nordh N-E Manual for Salix Growers (In Swedish)

Hall. R.L. Nlen, S.j. Rosier, P.T.W. Hopkins R. 1998. Transpiration from coppiced poplar and willow measured using sap flow methods Agric. Forest Met 90, 275-290.

Hasselgren, K_. 1998. Use of municipal waste products in energy forestry: high lights from 15 years of experience. Biomass Bioenergy 15, 71-74.

Larsson, S.2003, Short Rotation Willow Biomass Plantation Irrigated and Fertilized with Wastewaters - Results Form a 4-year Multidisciplinary Field Project in Sweden. France, Northem Ireland and Greece supported by the EU-FNR Programme (FAIRS-CT97-3947), Svalov, Sweden. Final Report.

Martin, P. Stephens, W, 2006a. Willow growth in response to nutrients and moisture on a clay landfill cap soil. I: growth and biomass production. Bioresour. Technol. 97, 437-448.

Martin, P.J. Stephens, W, 2006b. Willow growth in response to nutrients and moisture on a clay landfill cap soil. II: water use. Bicresour. Technol. 97, 449-458.

Miljestyrelsen, 2003. Retningslinier for etablering af pileanlag op til $30 \mathrm{PE}$ Øblogisk byformyelse og spildevandsrensning. Nr. 25. Miljestyrelsen, Copenhagen.

Mulqueen, J. Rodgers, M., 2001. Percolation testing for hydraulic conductivity of soils for percolation areas. Water Res. 35 (16), 3909-3915.

Pauliukonis, N. Shneider, R, 2001. Temporal patterns in evapotranspiration from lysimeter with three common wetland plant species in the eastern United States. Aquat. Bot. 71, 35-46.

Peeples, J_ Mancl, K. 1998. Laboratory scale septic tanks. Ohio J. Sci. 98 (4/5), 75-79.

Persson, G. 1995. Willow stand evapotranspiration for Swedish soils Agric. Water Manage. 28, 271-293.

Pistocchi, C Guidi, W. Piccioni. E. Bonari, E. 2009. Water requirements of poplar and willow vegetation filters grown in lysimeter under Mediterranean conditions: results of the second rotation. Desalination 247, 138-147.

Rosenquist, H. Aronsson, P. Hasselgren, K. Perttu, K., 1997. Economics of using municipal wastewater irrigation of willow coppice crops Biomass Bicenergy 12. $1-8$.

Running S.W. Nemani, R.R. Peterson, D.L. Ban, LE, Potts D.F, Pierce, L.L. Spanner, MA. 1989. Mapping regional forest evapotranspiration and photosynthesis by coupling satellite data with ecosystem simulation. Ecology 70 , $1090-1101$

Sugiura, A. Tyrrel, S. Seymour, L. 2008. Growth and water use of Salix viminalis Populus trichocarpa and Eucalyptus gunnii field trial plantation irrigated with secondary treated effluent. In: Aspects of Applied Biology. Biomass and Energy Crops III, pp. 119-126. 